UNDERGRADUATE RESEARCH IN NATURAL AND CLINICAL SCIENCE AND TECHNOLOGY (URNCST) JOURNAL Read more URNCST Journal articles and submit your own today at: https://www.urncst.com

\title{
Fixing Pitx3 gene Mutation with CRISPR-Cas9 Intervention in Zygotic Aphakia-Prone Mice - A Research Protocol
}

Hussam A. Sheikh, HBSc Student [1]*, Hassan Alibhai, HBSc Student [1], Gowsith Thilliaimbalam, HBSc Student [1]

[1] Department of Biological Sciences, University of Toronto, Toronto, Ontario, Canada

*Corresponding Author: ha.sheikh@mail.utoronto.ca

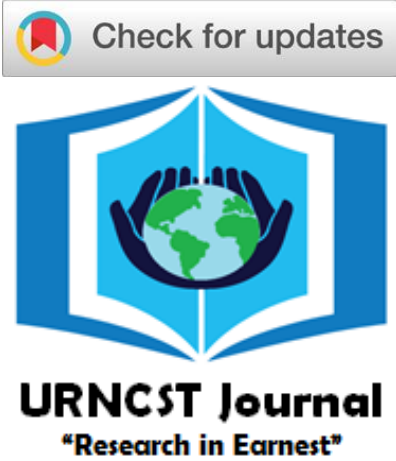

\begin{abstract}
Introduction: Despite the drawbacks of gene-editing, CRISPR-Cas9 remains a versatile tool for editing mutated genes. The mutated Pitx 3 gene may cause aphakia in mice and Parkinsonism in humans. Pitx 3 gene codes for the Pitx 3 transcription factor involved in many tasks including the differentiation of dopaminergic neurons in the substantia nigra, tyrosine hydroxylase expression, dopamine transporter and lens development. We aim to edit mutated Pitx3 genes using CRISPRCas9 in embryonic-dopaminergic progenitor-neurons of mice and compare to wildtypes (WT) that do not undergo CRISPRCas9 intervention.

Methods: We will use 5 female mice, 2 homozygous for mice aphakia/Pitx 3 mutation (Ak) and 3 standard pseudo-pregnant females. 2-male homozygous $(+/+\mathrm{Ak})$ mice with $\mathrm{Ak}$ will mate with the aphakic females $(+/+\mathrm{Ak})$. Dopamine levels in both (aphakic/non-aphakic) mice will be determined. We will extract embryonic stem cells (ESC) from aphakic female's uterus and treat with CRISPR-Cas9 and homology-directed repair (HDR). Both treated and untreated ESC will be divided between 3 pseudo-pregnant females. Post-parturition, intervention success will be assessed using presence of optical lens, dopamine levels and restriction sequence expression in treated/untreated progeny.

Results: We expect to observe that the untreated ESC zygotes (no CRISPR-Cas9 and HDR treatment) will not express normal Pitx3. This will result in low dopamine levels (inappropriate dopamine levels for their age group) and an aphakic mice progeny. Likewise, treated ESC zygotes will express normal Pitx3, hence have normal dopamine levels and nonaphakic phenotype.

Discussion: Progeny of both groups (treated/non-treated) will be examined for aphakia, dopamine levels and restriction sequence. Dopamine levels of treated mice will be compared to dopamine levels of WT mice. Should none of the treated progeny develop lenses or have normal dopamine levels, these mice will be sacrificed to target the restriction sequence in the inserted gene - helping to evaluate why the inserted gene is unexpressed.

Conclusion: This research examines CRISPR-Cas9 and HDR use on embryos with mutated genes that impair lens development and dopaminergic-neuron differentiation in humans and mice. It has potential of qualifying for clinical trials as the technique may be used to fix heritable disease-inducing genes that decrease longevity and quality of life in humans.
\end{abstract}

Keywords: dopaminergic neurons; substantia nigra; dopamine; differentiation; aphakia; CRISPR-Cas9; pseudo-pregnant; development

\section{Introduction}

The clustered regularly interspaced short palindromic repeat (CRISPR) system is a family of DNA sequences found within the genomes of prokaryotic organisms. It functions as an adaptive immune system in both bacteria and archaea. Cas9 is an enzyme that uses CRISPR sequences as a guide to recognize and cleave specific strands of DNA that are complementary to the CRISPR sequence. Cas9 enzymes together with CRISPR sequences form the basis of the technology known as CRISPR-Cas9 which is used to edit genes within organisms. [1] When it comes to mice- our model organism of choice - using CRISPR-Cas9 in order to produce "targeted genomic mutations" is already a proven, successful technique in mice embryos - as demonstrated by Scott and Gruzdev in their publication, Methods in Molecular Biology 2019 [2]. The Pitx3 gene is an autosomal dominant gene affecting early development in mice and humans [3]. Parts of this gene encodes transcription factors involved in early eye development and the proliferation and upkeep of mesencephalic dopaminergic neurons in the zygotic neural tube. [4]. In fact, lacking the Pitx3 transcription factor causes early embryonic termination of SN DA neurons [5]. Owing to the lack of the Pitx 3 transcription factors, the inability to produce dopamine by the substantia nigra may cause early Parkinsonism (PD) and aphakia. CRISPR-Cas9 
is used to remove the mutated Pitx3 gene and insert a corrected DNA template for the same gene using homology-directed repair at the same location. Doing so will maintain the natural course of embryonic cell development while fixing a mutated gene that could have otherwise resulted in unfit progeny. In humans, Pitx3 occurs on Chromosome 10, between 102230189 and 102241512 base pairs, and in mice, the gene occurs on Chromosome 19, between 46135685 and 46148326 base pairs [6,7]. Mice are an excellent model for experimentation when it comes to gene editing in embryos. This is because they share the majority of the same sequence of the Pitx3 gene with humans and also reproduce lots of progeny rapidly. A lot of the success of this experiment relies on the timing at which procedures are done. This includes the time at which the pregnancy is declared (E1.0) or the time at which the treatment of CRISPR-Cas9 and HDR is administered. The advantage that mice provide here is that they have a very small gestational period and offer a lot of genomic similarity to humans - especially the Pitx3 gene. Given the $98 \%$ similarity among the 302 amino acids made by the aforementioned gene [4], we were not able to find any other organism that can offer a chance to carry out this experiment over such a short period (gestation: 19 to 21 days), while also offering a big litter to test the success of the treatment. Mice with aphakia have a 5' deletion upstream of the Pitx3 gene that inhibits expression of its transcription factors. Our proposed research intends to investigate whether early CRISPR-Cas9 intervention, as outlined by Scott and Gruzdev, can help mitigate the observed phenotype caused by the mutation in the Pitx 3 gene [2].

\section{Methods \\ Mice Treatment Groups}

Prior to intervention, 4 mice of the strain 129/SV-SIJ and 3 pseudo-pregnant mice of strain C57BL/6 (nonaphakic strain) will be purchased from the Jackson Laboratories and weighed daily [9,10]. Pseudo-pregnant mice are female mice that behave hormonally pregnant after having copulated with sterile males. This makes them ready to accept embryos [11]. 4 of the mice would have aphakia and therefore the presence of the Pitx3 gene mutation (Figure 1).

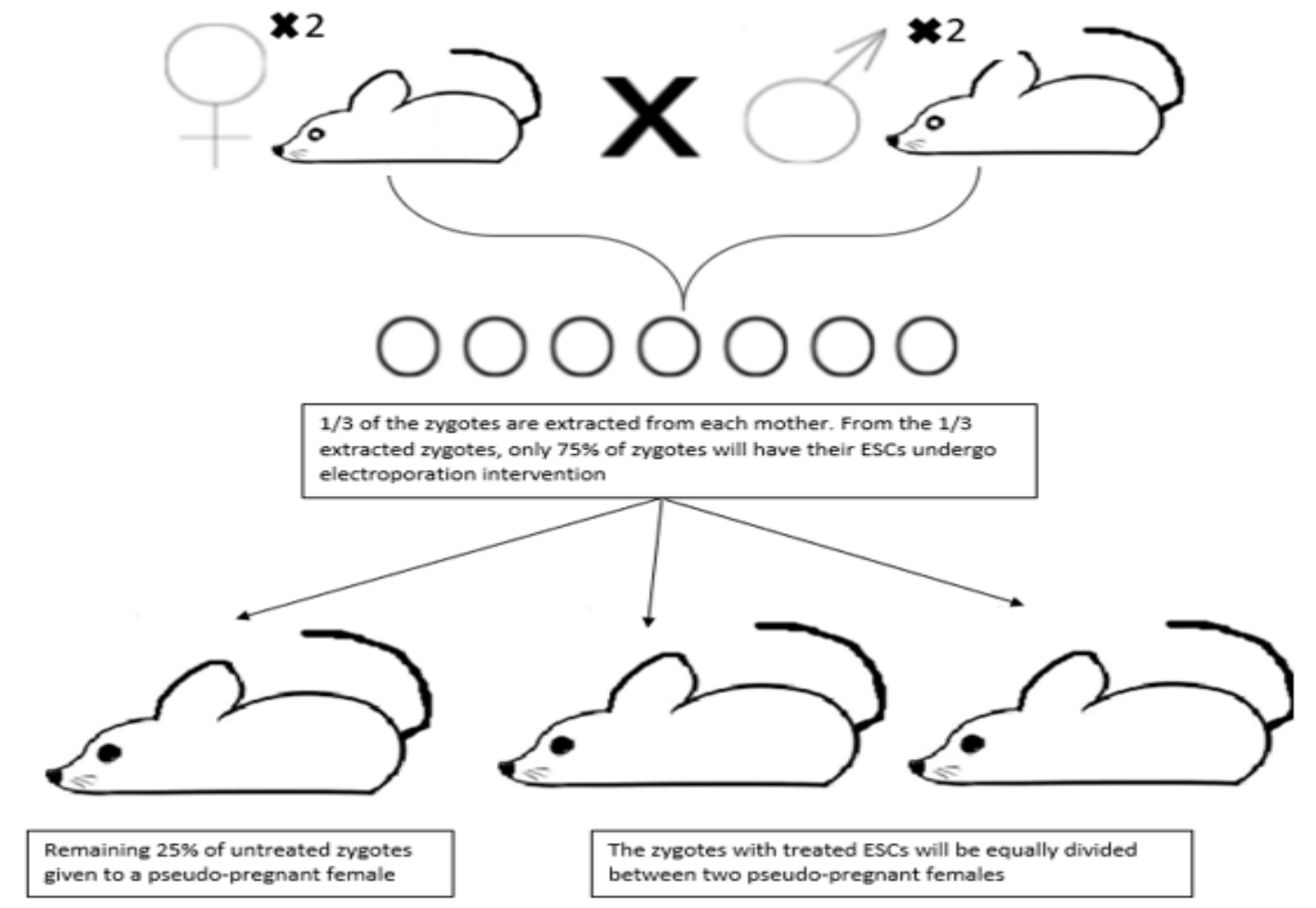

Figure 1. ESCs of aphakic zygotes undergo CRISPR Cas9-HDR intervention at Embryological stage 4 (E4.0) via electroporation. The zygotes with treated ESCs will be implanted into pseudo-pregnant females and their offspring will be evaluated. Figure was created using Microsoft Word software.

We will use 2 males and 2 females of 129/SV-SIJ strain, homozygous for aphakia (+/+ Ak). All 4 will be 12 weeks postnatal. The 3 pseudo-pregnant mice of strain

Sheikh et al. | URNCST Journal (2021): Volume 5, Issue 10

DOI Link: https://doi.org/10.26685/urncst.293
C57BL/6 will be 13 weeks postnatal. Both aphakic couples would be separated to different rooms but the pseudopregnant mice will be kept together in a room during 8 days 
of acclimatization. The couples and the pseudo-pregnant mice would have a constant supply of food, water, and a stable room temperature $\left(25^{\circ} \mathrm{C}\right)$ throughout the experiment. Should the homozygous dominant couple mate, the litter will comprise $100 \%$ affected individuals. The aphakic females will be examined every 12 hours for vaginal plugs as proof of copulation [10]. Upon the increase in weight noticed after the presence of vaginal plugs; we confirm pregnancy and Embryological day 1 - E1.0 [12].

\section{Measurement of Age-Appropriate Dopamine Levels}

During this acclimatization period, one of the couples and a pseudo-pregnant mouse will be tested for their dopamine levels using fallypride injections under PET scanner and the dopamine levels will be evaluated. Since fallypride has an affinity for the dopamine receptors, we expect that the fallypride will accumulate more in the brains of mice that have a mutated Pitx3 gene, than in mice brains that have a fixed Pitx3 gene. This will be noticed as receptors are upregulated when there are less ligands but are downregulated when there is ample ligand present [8].

\section{Extraction and Preservation of ESC}

After E4.0, both pregnant females will undergo cesarean to extract embryos [13]. The number of embryos harvested will be approximately $1 / 3 \mathrm{rd}$ of the total number of embryos present (Figure 1). After harvesting 1/3rd embryos from both Ak females, the maturing ESC will be obtained using $27 \mathrm{G}$ needles and will be incubated in plastic culture dishes containing various growth factors and extracellular Matrigel [14]. The culture dishes will be maintained in water jacketed $\mathrm{CO}_{2}$ incubators till CRISPR-Cas9 and HDR intervention is set up $[15,16]$. Embryo-cryopreservation will be done to maintain the embryos in-vitro [17].

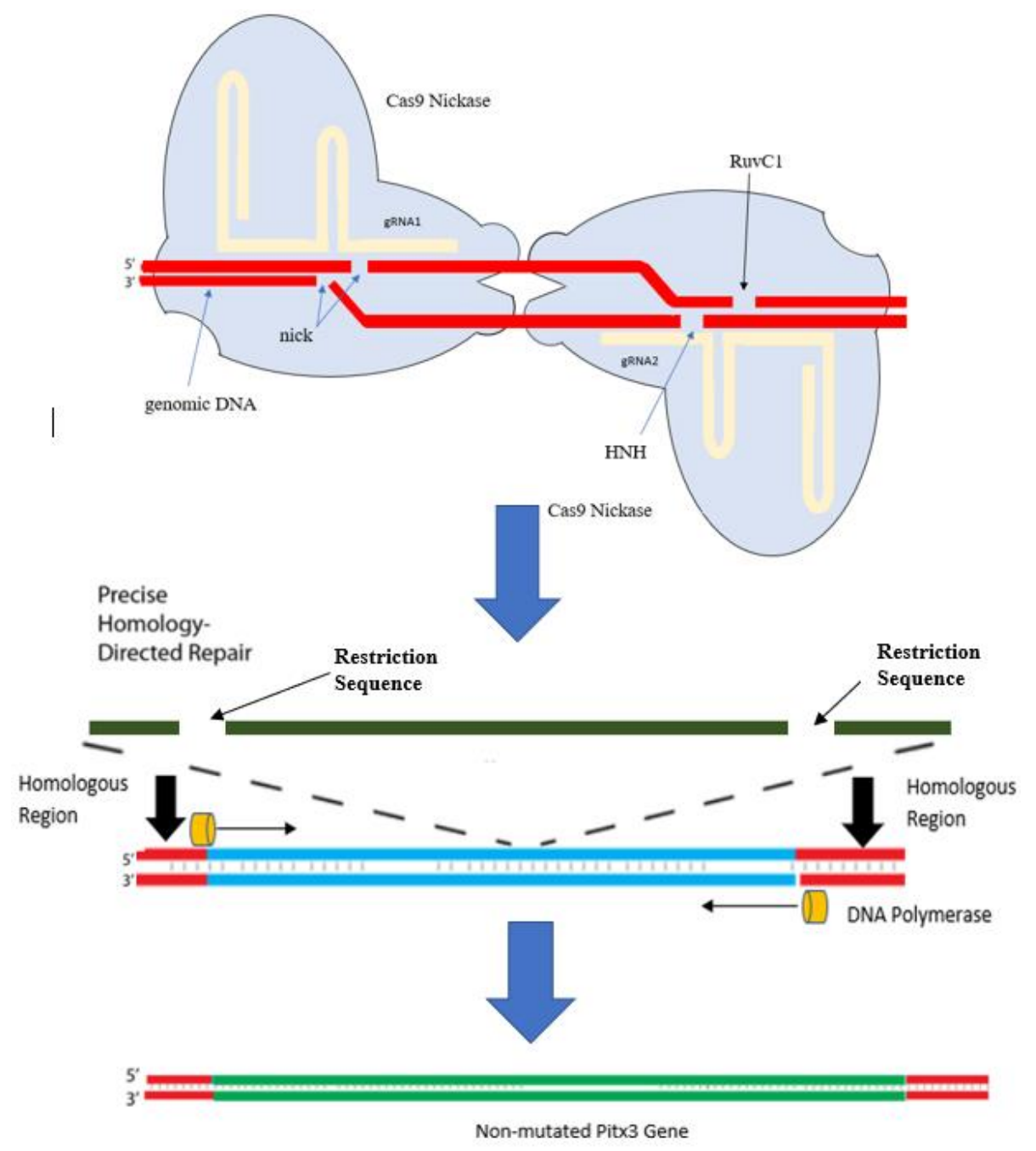

Figure 2. Embryonic stem cells of selected $75 \%$ zygotes undergo electroporation allowing CRISPR Cas9-HDR sequence into the cell. Then, CRSPR Cas9 and HDR will target and edit the mutated Pitx3 gene. Figure was created using Microsoft Word software. 
UNDERGRADUATE RESEARCH IN NATURAL AND CLINICAL SCIENCE AND TECHNOLOGY (URNCST) JOURNAL Read more URNCST Journal articles and submit your own today at: https://www.urncst.com

PCR, Restriction Sequencing, Electroporation, \& CRISPRCas9 and HDR Intervention

A DNA repair template of the normal Pitx3 gene with restriction sequences added on both ends of the DNA template that will be prepared (Figure 2). A DNA repair template of the normal Pitx3 gene with restriction sequences added on both ends of the DNA template will be prepared (Figure 2). To prepare the Pitx3 DNA template, we will conduct Polymerase Chain Reaction (PCR) on DNA from the pseudo-pregnant females; in order to amplify the normal Pitx3 DNA sequence. This sequence once amplified will be isolated and restriction sequences using DNA polymerase will be added. Subsequently, the Pitx3 DNA template prepared with the restriction sequences will then be electroporated into ESC along with 2 prepurchased purified Cas9 (from TriAtlus Bioscience) coupled with sgRNA; each complex creating nicks at either ends of the gene for complete gene excision (Figure 2). Only $75 \%$ of harvested embryos will undergo electroporation (Figure 2). Electroporation will be conducted using a custom-made electroporation chamber with two platinum block electrodes $(10$-millimeter $(\mathrm{mm})$ long, 3-mm wide and $0.5 \mathrm{~mm}$ thick) situated within a $1-\mathrm{mm}$ gap [19]. We will conduct an electroporation voltage of 30 volts within 7 repeats within 3 milli-second pulses for efficient conditions for CRISP-Cas9 intervention [19]. The extracted ESC will take up the Pitx3 DNA template and 2 Cas9-sgRNA complexes for the excision of mutated Pitx3 sequence (Figure 2) [20-22]. The harvested embryos will be maintained in-vitro till electroporation of ESC is completed.

Examination of Phenotypic and Genetic Expression among Treatment Groups

24 hours after electroporation, the maturing ESC are microinjected back into the respective harvested embryos and the embryos are implanted into the pseudo-pregnant mice through a technique - transcervical embryo transfer $[23,24]$. Embryos with electroporated ESC will be equally divided into 2 pseudo-pregnant mice, while the $3 \mathrm{rd}$ pseudopregnant mouse will get $25 \%$ of embryos that had not undergone any treatment and consequently should have aphakic progeny (Figure 1). Post-parturition, the progeny with electroporated ESC will be examined for a fully developed and functional optical lens. As progenies become 12 weeks post-natal, dopamine levels will be tested by injecting radioactive fallypride (that has high affinity for dopamine receptors) and PET camera scan. If there is a lack of both the optic lens and age-specific dopamine levels, we trace the restriction sequence on either ends of the inserted gene by sacrificing the mice.

\section{Results}

Post-parturition, it is anticipated that the ESC zygotes that had not been treated with the CRISPR-Cas9 and HDR treatment, would have an absence of the Pitx3 expression; hence have low dopamine levels (inappropriate dopamine levels for their age group) and an aphakic mice progeny. ESC-zygotes that undergo HDR and CRISPR-Cas9 treatment would develop into mice that possess optic lenses and age-appropriate levels of dopamine as the corrected Pitx3 gene gets expressed. As shown in previous research, dopamine levels decreased in the absence of Pitx3 while dopamine expression was unaltered in presence of normal Pitx3 [25] in wildtype mice.

\section{Discussion}

Despite Pitx3 being an autosomal dominant gene, we will have conducted two biological and technical replicates to ensure treated progenies carry corrected Pitx 3 genes. The first biological replicate examines the development of the extracted eggs with or without CRISPR-Cas9 and HDR treatment between the pseudo-pregnant females. The second biological replicate examines the mother's impact on the development of the untreated embryos between original and pseudo-pregnant females. The first technical replicate examines the phenotypic and gene expression of aphakia/Pitx3 mutation in untreated pseudo-pregnant mice and remnant progenies in original mice. The second technical replicate ensures that the implantation of the two treated ESC embryos inside two pseudo-pregnant females would grow similar phenotypic and gene expression of a mice with functional Pitx3 gene. The results from this research will be used to understand the effectiveness of the CRISPR-Cas9 intervention in embryological genome editing. The assessment of dopamine levels of aphakic and non-aphakic (pseudo-pregnant) mice prior to treatment gives the baseline levels of dopamine in mice. These levels prior to intervention assist in comparing the dopamine levels in treated and non-treated progeny (at 12 weeks postnatal). The presence of optical lens and normal dopamine levels are good indicators of a successful CRISPR-Cas9 treatment; proving that the CRISPR-Cas9 and HDR treatment can interfere to fix Pitx3 mutation. If there is a lack of both the optic lens and age-specific dopamine levels (indicating a malfunctioning Pitx3), the restriction sequence on either ends of the inserted gene can be traced by sacrificing the mice. This can evaluate why the gene was silenced (for example- due to methylation). The restriction sequence allows us to confirm whether or not the CRISPRCas9 and HDR had successfully implanted the edited gene by isolating the genetic sequence. These three indicators (i.e., dopamine levels, optical lens, and restriction sequence) can be used sequentially to assess the success of the CRISPR-Cas9 and HDR in the treated progeny.

\section{Conclusion}

The goal of the research is to edit mutated Pitx3 genes using CRISPR-Cas9 and HDR in ESC of mice and compare them to the wildtypes (WT) that do not undergo CRISPRCas9 and HDR intervention. CRISPR-Cas9 has been hardly used in the past to repair faulty inherited genomic 
UNDERGRADUATE RESEARCH IN NATURAL AND CLINICAL SCIENCE AND TECHNOLOGY (URNCST) JOURNAL Read more URNCST Journal articles and submit your own today at: https://www.urncst.com

sequences in early embryonic development. We assess the prospects of CRISPR-Cas9 and HDR intervention in stem cellular genome editing; while also providing an opportunity to prevent heritable diseases like PD from affecting offspring. As a result of the Pitx3 gene mutation, conditions like aphakia in mice and PD in humans emerge. Examining how to fix such genes during prenatal development using CRISPR-Cas9 allows scientists to learn and prevent such harmful genetic inheritances from taking their natural course. Since the gene studied in this research is found in mice and humans, this research protocol holds strong prospects for clinical application as it could delay/eliminate PD in particularly vulnerable groups. Despite the clinical prospects, it is important to know that there are several genes, other than the Pitx3 gene, that are involved in the differentiation of the dopaminergic neurons in the substantia nigra. This research protocol is only limited to testing the genome editing of the Pitx3 gene at a certain embryological developmental stage using CRISPRCas9 and HDR technology. In addition to the clinical prospects, this research can also be a trend-setter for genome editing in plants; hence allowing plants to grow better and nutritious produce for the rapidly increasing global population. Since the technology offers targeted gene editing, this can be used in the prokaryotic genome to allow for synthesis of enzymes that can be used in scientific experimentation. The limitations include the chance of CRISPR-Cas9 to mistarget a gene, hence causing a major unintended mutation instead of correcting a faulty gene sequence. Another key limitation is the rather inconsistent rate of uptake and response, [26] potentially limiting the formation of zygotes with the corrected Pitx3 gene. Furthermore, after electroporation, we will not track the CRISPR-Cas9 treatment using GFP (green fluorescent protein), hence remaining oblivious to where the Pitx3 DNA template gets integrated in the genome. However, although tracking using GFP could improve results, our methodology assesses the success of the CRISPR-Cas9 and HDR treatment by assessing phenotypic manifestation like optical lens and age-appropriate dopamine levels. In case of inappropriate dopamine levels and absence of optical lens, we will assume that the treatment was unsuccessful with the CRISPR-Cas9 and HDR. Consequently, the reason for failure will be examined using restriction enzymes that target restriction sequences in the inserted Pitx3 DNA template that has failed to express. CRISPR-Cas9 has been a debatable technology due to its ability to edit the genome of cells in embryos. The technology is often seen as unethical and a means to interfere in the natural course of development. Since this protocol tends to attempt the same, the likelihood of its recognition and use on other organisms remains uncertain. The applicability of CRISPR-Cas9 and HDR in human embryos remains untested. Therefore, more research is needed to make sure that this gene-editing technology safely targets and edits the genomic sequence in human embryos.

Sheikh et al. | URNCST Journal (2021): Volume 5, Issue 10

DOI Link: https://doi.org/10.26685/urncst.293

\author{
List of Abbreviations Used \\ DNA: deoxyribonucleic acid \\ HDR: homology directed repair \\ ESC: embryonic stem cells \\ sgRNA: single guide ribonucleic acid \\ $\mathrm{DN}$ : dopaminergic neurons \\ DA: dopamine \\ PD: Parkinson's disease \\ WT: wildtype \\ Ak: aphakia \\ PET: positron emission tomography \\ SN: substantia nigra
}

\section{Conflicts of Interest}

The author(s) declare that they have no conflict of interests.

\section{Ethics Approval and/or Participant Consent}

This research protocol uses mice and would therefore require ethics review. Participant consent is not required as the research involves no human participants.

\section{Authors' Contributions}

HAS: made contributions to the design of the study, drafted the manuscript, and gave final approval of the version to be published.

HA: contributed to study design and planning, drafted the manuscript and gave final approval of the version to be published

GT: made substantial contributions to the design of the study, revised the manuscript critically, and gave final approval of the version to be published.

\section{Acknowledgements}

We thank and acknowledge the support provided by Dr. Aarthi Ashok at the University of Toronto during the preparation of this research protocol.

\section{Funding}

This study was not funded

\section{References}

[1] Jiang F, Doudna J. CRISPR-Cas9 structures and mechanisms. Annual Review of Biophysics. 2017 May 22;46(1):505-29. https://doi.org/10.1146/annurevbiophys-062215-010822

[2] Scott GJ, Gruzdev A. Genome editing in mouse embryos with CRISPR/Cas9. Mouse Models of Innate Immunity. 2019 Feb 24;1960:23-40. https://doi.org/ 10.1007/978-1-4939-9167-9_2

[3] Semina E, Ferrell R, Mintz-Hittner H, Bitoun P, Alward W, Reiter R et al. A novel homeobox gene PITX3 is mutated in families with autosomal-dominant cataracts and ASMD. Nature Genetics. 1998 Jun;19(2):167-170. https://doi.org/10.1038/527 
UNDERGRADUATE RESEARCH IN NATURAL AND CLINICAL SCIENCE AND TECHNOLOGY (URNCST) JOURNAL

Read more URNCST Journal articles and submit your own today at: https://www.urncst.com

[4] Zhou F, Li L, Yue J, Dani J. Transcription factor PITX3 mutant mice as a model for Parkinson's disease. Frontiers in Biology. 2016 Dec 07;11(6):427-438. https://doi.org/10.1007/s11515-016-1429-8

[5] Smidt M, Smits S, Bouwmeester H, Hamers F, van der Linden A, Hellemons A et al. Early developmental failure of substantia nigra dopamine neurons in mice lacking the homeodomain gene Pitx3. Development. 2004 March 01;131(5):1145-1155. https://doi.org/ $10.1242 / \mathrm{dev} .01022$

[6] Pitx3- Paired-Like Homeodomain Transcription Factor 3 (Pitx3) - MGI Mouse Gene Detail [Internet]. [cited Jun 3, 2021]. Available from: http://www.informatics.jax.org/marker/MGI:1100498.

[7] Paired-Like Homeodomain Transcription Factor 3 (PITX3) [Internet]. [cited Jun 3, 2021]. Available from: http://atlasgeneticsoncology.org/Genes/GC PITX3.html

[8] Bittner E, Martyn J. Neuromuscular physiology and pharmacology. Pharmacology and Physiology for Anesthesia. 2019:309-324. https://doi.org/10.1016/ B978-0-323-48110-6.00021-1

[9] PITX3 mice [Internet]. Neurodegenerative Disease Research. [cited 24 Aug 2021]. Available from: https://www.neurodegenerationresearch.eu/models-forparkinsons-disease/in-vivo-mammalian-models/Pitx3mice/.

[10] Heyne GW, Plisch EH, Melberg CG, Sandgren EP, Peter JA, Lipinski RJ. A simple and reliable method for early pregnancy detection in inbred mice. Journal of the American Association for Laboratory Animal Science. 2015 Jun;54(4):368-71. Available from: http://www.ncbi.nlm.nih.gov/pmc/articles/pmc4521569 1

[11] Ganten D, Klaus, Birchmeier W, Epplen JT, Genser K, Gossen M, et al. Pseudopregnant mouse. Encyclopedic Reference of Genomics and Proteomics in Molecular Medicine. 2006;1578-1578. https://doi.org/10.1007/3540-29623-9_8423

[12]Coan P, Ferguson-Smith A, Burton G. Developmental dynamics of the definitive mouse placenta assessed by stereology. Biology of Reproduction. 2004 Jun;70(6):1806-1813. https://doi.org/10.1095/biolreprod .103 .024166

[13] Hill M. Mouse Timeline Detailed - Embryology [Internet]. Embryology.med.unsw.edu.au. [cited 24 August 2021]. Available from: https://embryology .med.unsw.edu.au/embryology/index.php/Mouse Time line Detailed

[14] Khan F, Almohazey D, Alomari M, Almofty S. Isolation, culture, and functional characterization of human embryonic stem cells: Current trends and challenges. Stem Cells International. 2018 Aug 26;2018:1-8. https://doi.org/10.1155/2018/1429351
[15] Itoi F, Tokoro M, Terashita Y, Yamagata K, Fukunaga $\mathrm{N}$, Asada $\mathrm{Y}$ et al. Offspring from mouse embryos developed using a simple incubator-free culture system with a deoxidizing agent. PLoS ONE. 2012 Oct 09;7(10):e47512. https://doi.org/10.1371/journal.pone .0047512

[16] Amit M, Itskovitz-Eldor J. Embryonic stem cells: Isolation, characterization and culture. Engineering of Stem Cells. 2009 Jun 03:173-184. https://doi.org/ $10.1007 / 10 \_2008 \quad 20$

[17] Kasai M, Komi J, Takakamo A, Tsudera H, Sakurai T, Machida T. A simple method for mouse embryo cryopreservation in a low toxicity vitrification solution, without appreciable loss of viability. Reproduction. 1990 Jan 01;89(1):91-97. https://doi.org/10.1530/ irf.0.0890091

[18] Tony abm. CRISPR Cas9 - gRNA Design [Internet]. Applied Biological Materials Incorporated. [cited 2021 Aug 24]. Available From: https://www.abmgood.com/marketing/knowledge base /CRISPR_Cas9_gRNA_Design.php

[19] Hashimoto M, Takemoto T. Electroporation enables the efficient mRNA delivery into the mouse zygotes and facilitates CRISPR/Cas9-based genome editing. Scientific Reports. 2015 Jun 11;5(1). https://doi.org/10.1038/srep11315

[20] Lino CA, Harper JC, Carney JP, Timlin JA. Delivering CRISPR: A review of the challenges and approaches. Drug Delivery. 2018 Feb 24 ;25(1):1234-57. https://doi.org/10.1080/10717544.2018.1474964

[21] CRISPR (Clustered Regularly Interspaced Short Palindromic Repeat) Guide. addgene; [cited 2021 Aug24]. Available from: https://www.addgene .org/guides/crispr/\#

[22] Potter H. Transfection by electroporation. Current Protocols in Molecular Biology. 2003 May 15;62(1). https://doi.org/10.1002/0471142727.mb0903s62

[23] Tompers DM, Labosky PA. Electroporation of murine embryonic stem cells: A step-by-step guide. Stem Cells. 2009 Jan 02; 22(3):243-9. https://doi.org/ 10.1634/stemcells.22-3-243

[24] Garcia-Dominguez X, Marco-Jimenez F, Viudes-DeCastro MP, Vicente JS. Minimally invasive embryo transfer and embryo vitrification at the optimal embryo stage in rabbit model. Journal of Visualized Experiments. 2019 May 16;(147). https://doi.org/ $\underline{10.3791 / 58055}$

[25] Nunes I, Tovmasian LT, Silva RM, Burke RE, Goff SP. Pitx3 is required for development of substantia nigra dopaminergic neurons. Proceedings of the National Academy of Sciences. 2003 Apr 01;100(7):4245-50. https://doi.org/10.1073/pnas.0230529100 
UNDERGRADUATE RESEARCH IN NATURAL AND CLINICAL SCIENCE AND TECHNOLOGY (URNCST) JOURNAL

Read more URNCST Journal articles and submit your own today at: https://www.urncst.com

[26] Jacquet ADR, Denis HL, Cicchetti F, Alpaugh M.

Correction to: Current and future applications of

induced pluripotent stem cell-based models to study

pathological proteins in neurodegenerative disorders.

Molecular Psychiatry. 2021 Mar 09.

https://doi.org/10.1038/s41380-021-01055-8

\section{Article Information}

Managing Editor: Jeremy Y. Ng

Peer Reviewers: Foram Vyas, Siobhan O’Brien

Article Dates: Received Jun 04 21; Accepted Sep 01 21; Published Oct 621

\section{Citation}

Please cite this article as follows:

Sheikh HA, Alibhai H, Thilliaimbalam G. Fixing Pitx3 gene mutation with CRISPR-Cas9 intervention in zygotic aphakiaprone mice - A research protocol. URNCST Journal. 2021 Oct 6: 5(10). https://urncst.com/index.php/urncst/article/view/293 DOI Link: https://doi.org/10.26685/urncst.293

\section{Copyright}

(c) Hussam A. Sheikh, Hassan Alibhai, Gowsith Thilliaimbalam. (2021). Published first in the Undergraduate Research in Natural and Clinical Science and Technology (URNCST) Journal. This is an open access article distributed under the terms of the Creative Commons Attribution License (https://creativecommons.org/licenses/by/4.0/), which permits unrestricted use, distribution, and reproduction in any medium, provided the original work, first published in the Undergraduate Research in Natural and Clinical Science and Technology (URNCST) Journal, is properly cited. The complete bibliographic information, a link to the original publication on http://www.urncst.com, as well as this copyright and license information must be included.

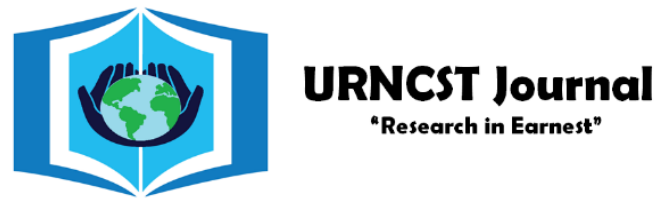

\section{Funded by the Government of Canada}

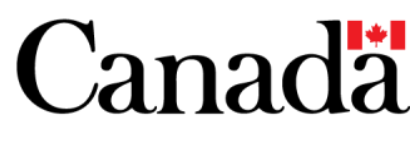

Do you research in earnest? Submit your next undergraduate research article to the URNCST Journal!

| Open Access | Peer-Reviewed | Rapid Turnaround Time | International | | Broad and Multidisciplinary | Indexed | Innovative | Social Media Promoted |

Pre-submission inquiries? Send us an email at info@ urncst.com | Facebook, Twitter and LinkedIn: @URNCST

Submit YOUR manuscript today at https://www.urncst.com! 